\title{
Free Movement Emancipates, but What Freedom Is This?
}

\author{
Vesco Paskalev
}

I must start my response to Floris de Witte with a personal note - I am a Bulgarian national, living and working in Britain. As such, I am strongly attracted by his argument that sees free movement as the core of EU citizenship aimed at extending individual liberties. Indeed, my moving away from Bulgaria was an act of emancipation from the perennially corrupt and increasingly fascist country where I was born. Contrary to what Daniel Thym and Richard Bellamy argue, the Member States, while nominally democratic, do differ in their respect for fundamental rights of their citizens, and the professed ambitions of the current Hungarian prime minister to build an illiberal state does not seem to suggest that convergence towards the highest democratic standards is forthcoming.

Indeed, freedom of movement is emancipatory in a number of senses. On a conceptual level, EU citizenship liberates everyone: for centuries contractarian theories have claimed that people who do not leave their country of residence can be seen as consenting to its authority. While until recently the exit option has been only putative, now EU citizenship allows us to conceive those who stay as accepting state authority voluntarily. Certainly, EU citizenship should be the dream of libertarians - in a marketplace of governments you can shop around and chose the one which is freer, or perhaps the one which is best tailored to your personal taste. EU citizenship is emancipatory also in pragmatic terms (one may call this argument neoliberal) - the fear of possible mass exit of citizens (a.k.a. workforce, taxpayers, electorate) may deter governments from abusing them. All in all, if we equate freedom with individual pursuit of happiness in a social context that is taken for granted, it is difficult to argue against De Witte. However, it is not so on a more robust, Arendtian understanding of freedom as equal participation in a self-governing community, which free movement tends to erode.

Certainly, De Witte (and all of the previous contributors) do not understand freedom negatively. Indeed free movement may promote certain positive aspects of freedom. For example, De Witte correctly argues that free movement 'liberates not only the body but also the mind from the normative 
structures of the state.' The Brexit referendum provides a wonderful empirical confirmation of this point. Opinion polls suggest that while older Britons are clinging on antiquated ideas about sovereignty, the younger generation born as EU citizens and in conditions of widespread mobility - are very much at ease with joint decision-making and are more likely to see the Union as empowering rather than crippling their own country. ${ }^{1}$ There is no similar evidence for the attitudes of older Britons living in Europe, but it is plausible to expect some similarity between the views of the people who actually move and of those who are born with the right to. ${ }^{2}$ There is 'reflexive virtue' to be gained from free movement indeed.

Such collateral benefits of free movement notwithstanding, civic virtue is ill served by free movement and it is hardly surprising that Richard Bellamy disagrees with De Witte. On republican accounts citizenship is relational and European mobility by definition loosens the link between citizens and their state. Even in the age of Ryanair and Skype the opportunities of the external citizens to participate in the democratic life of their home state are significantly reduced. Indeed, in most cases they retain the right to vote, and its exercise abroad is often - but not always - facilitated by postal, proxy and e-voting. But democracy is so much more than the ballot box! Citizens who do not move can go on rallies, volunteer for various causes, join political organisations, speak in public or engage in community initiatives. One need not subscribe to Pierre Rosanvallon's concept of counter-democracy ${ }^{3}$ to agree that all this is part and parcel of any democracy. Thus, on the more robust understanding of freedom, which encompasses equal opportunity for participation in the collective system of governance, free movement inevitably reduces freedom. The fact that the mobile citizens have moved out freely may satisfy contractarians but not civic republicans. As long as the link with the home state is not broken completely - which may happen eventually the freedom of the external citizens is limited in this sense.

1 A YouGov poll found that the intergenerational gap is immense " 73 per cent of those aged between 18-29 want to remain in the EU, while 63 per cent of those aged over 60 want to leave', The Telegraph, 12 May 2016, available at http:// www.telegraph.co.uk/news/2016/03/21/

eu-referendum-who-in-britain-wants-to-leave-and-who-wants-to-rem/.

2 Some anecdotal evidence available in Paxman goes to Brussels: Who really rules us? BBC Documentary, first shown 19 May 2016, available at http:// www.bbc.co.uk/iplayer/episode/b07c6n58/ paxman-in-brussels-who-really-rules-us.

3 Rosanvallon, P. (2008), Counter-Democracy: Politics in an Age of Distrust. Cambridge: Cambridge University Press. 
Now, this attenuated freedom might be normatively satisfactory as the stake of the external citizens in their country of origin is decreased, too. ${ }^{4}$ And of course, along with the freedom to move, the EU citizens now have uniquely - extensive rights to participate in the democratic governance of the EU itself, which remain unaffected by their movement. Further to this, from day one EU citizens have enjoyed significant rights to participate in the political process of the host state. Apart from the electoral franchise, the rights of participation they have there, albeit limited, roughly correspond to the rights which are difficult to exercise from a distance in the home state. It might appear that freedom - even republican freedom - lost equals freedom gained. The problem is that in practice the external citizens are far less likely to exercise the rights they have in the host state than they would exercise equivalent rights in their state of origin. While your ability to attend a rally ceases on the day you have left the country, it is highly unlikely that you would participate in another rally on the day you arrived in your new country of residence. Notwithstanding the legal rights the Treaties will give, there is an inevitable lag before a mobile citizen integrates in the political process of the host state to the degree he or she was integrated in the home state. For this period - and it can be very long - the mobile citizens are losing a significant aspect of their freedom due to their movement.

This may all appear trivial. Indeed, reality rarely conforms fully to our normative expectations; even in the simplest case of national voting not every single citizen has effective and equal opportunity to vote and we are still satisfied when the overwhelming majority does. As long as only about 15 (out of 508) million EU citizens ${ }^{5}$ have actually moved one may be right not to lose much sleep over the impact on democracy in the EU. The problem is one of aggregation. Republican freedom, and democracy in general, depend on a critical number of citizens who do participate actively in the political process. When fewer people participate - in voting and in the informal modes of contestation - the robustness of freedom decreases for all. Indeed, one of the main reasons for the democratic deficit of the EU is alleged to be the low turnout in elections for the European Parliament. This

4 For a discussion see Bauböck, R. (2007), 'Stakeholder Citizenship and Transnational Political Participation: A Normative Evaluation of External Voting', Fordham L. Rev. 75 (5): 393-447.

5 Eurostat, see data available at http://ec.europa.eu/eurostat/statistics-explained/index.php/Migration_and_ migrant_population_statistics. 
is the darker side of free movement. Notwithstanding its apparent emancipatory effect for the individual citizens - which may well outweigh what is lost in terms of non-participation - it tends to decrease, rather than increase republican freedom in Europe.

Open Access This chapter is licensed under the terms of the Creative Commons Attribution 4.0 International License (http://creativecommons.org/licenses/by/4.0/), which permits use, sharing, adaptation, distribution and reproduction in any medium or format, as long as you give appropriate credit to the original author(s) and the source, provide a link to the Creative Commons license and indicate if changes were made.

The images or other third party material in this chapter are included in the chapter's Creative Commons license, unless indicated otherwise in a credit line to the material. If material is not included in the chapter's Creative Commons license and your intended use is not permitted by statutory regulation or exceeds the permitted use, you will need to obtain permission directly from the copyright holder. 